\title{
Learning of Immigrant Entrepreneurs: Local Tacit Business Knowledge
}

\author{
Karen Y. Wang \\ University of Technology, Sydney \\ E-Mail: karen.yuan.wang@uts.edu.au \\ Chanida Kitvorametha \\ University of Newcastle, Australia \\ E-Mail: kitvorametha@hotmail.com \\ Yue Wang \\ Macquarie University \\ E-Mail: yue.wang@mq.edu.au
}

\begin{abstract}
The immigrant entrepreneurs' capabilities to recognize and gain tacit business knowledge are critical for their success in the host country. However, little scholarly attention has been given to the issue of business learning of immigrant entrepreneurs in a host country. Through multiple theoretical lenses, our study fills the gap by examining the extent to which the human and social capital of immigrant entrepreneurs is associated with the local business tacit knowledge learning in terms of learning capacities and facilitation. Based on a sample of immigrant entrepreneurs in Australia, the findings of our study indicate that industry-specific training and cultural similarity of cognitive social capital are related to immigrant entrepreneurs' tacit marketing knowledge learning. The formal education of context-generic human capital enables them with tacit financial knowledge learning. Moreover, trustworthiness of relational social capital plays a critical role in facilitating their learning in both tacit marketing and financial knowledge. This study contributes to the entrepreneurship literature by addressing issues of immigrant entrepreneurs' business learning.
\end{abstract}

Keywords: Tacit Marketing and Financial Knowledge, Relational and Cognitive Social Capital, Human Capital, Immigrant Entrepreneurs, Learning Capabilities and Facilitation 


\section{INTRODUCTION}

The positive impact of Asian immigrant entrepreneurs on economic and social aspects of host societies such as Australia, the USA and the UK, is increasingly evident (Collins, 2003; Kalnins \& Chung, 2006). Immigrant entrepreneurs are a special group of entrepreneurs who become self-employed by starting their own business in the host country. They usually lack recognised educational qualifications, do not have sufficient access to relevant social networks for transmitting information in the labour market in the host country, and local counterparts may discriminate against them (Rath, 2010). The business environment in host countries presented to immigrants may be complex and ill-structured, resulting in a high level of uncertainty (Simonin, 1999; Rath, 2010). For their businesses to survive and grow in such adverse environments, they must gain local expertise in strategic marketing and financial management. Such learning is often in the form of tacit and implicit experiences. Immigrant entrepreneurs' capability to recognise and acquire tacit business knowledge from local resources is essential for their economic success (Lee \& Lan, 2011; Wang et al., 2011). However, from the extant literature we know little about how immigrant entrepreneurs acquire tacit knowledge of business in the host country (Ilhan-Nas et al., 2011).

This study attempts to fill this gap by addressing the research question of how human capital and social capital play a role in the immigrant entrepreneurs' tacit knowledge learning. Based on learning theory and structure theory, we contend that to overcome the constraints in learning business knowledge, immigrant entrepreneurs resort to both learning-capabilities of human capital and learning-facilitation of social capital to acquire tacit marketing and financial knowledge (Davidsson \& Honig, 2003). Specifically, we examine the extent to which the context-generic and contextspecific human capital of immigrant entrepreneurs is related to the learning of tacit marketing and financial knowledge in a host country, and the extent to which relational social capital and cognitive social capital facilitates the learning of local tacit knowledge.

Acquisition of tacit knowledge is highly personalised and characterised by the fact that those who possess it are willing to demonstrate it (Nonaka, 1994). Transference of tacit knowledge is likely to take place between people who are socially tied to one another in a social-embedding process (Nonaka, 1994). The embedding process of learning is identified as focusing, persuading, aligning, adapting, and owning (Cranefield, 2009). Human capital provides immigrant entrepreneurs with learning capabilities but it is not sufficient to give them access to local tacit knowledge. Immigrant entrepreneurs cannot easily gain access to local tacit 
business knowledge unless they are embedded in ethnic networks, and become part of the process of social exchange (Jack \& Anderson, 2002). We explore the roles of human and social capital in the business learning of immigrant entrepreneurship.

Our study makes several contributions to the literature of entrepreneur learning. First, the study explicates immigrant entrepreneurs' learning capability in acquiring local tacit business knowledge in the host country from a perspective of contextrelated human capital. Our analysis addresses a weakness in previous studies which define a direct role of human capital in immigrants' earnings, but cannot explain how and why such human capital achieves the economic outcomes (Valdez, 2008). Second, by exploring the effect of trustworthiness, we analyse the learning-facilitative role played by relational social capital in immigrant entrepreneurs' local tacit knowledge learning. Although recognising an information role in immigrant entrepreneurship, previous research tends to ignore its facilitating role in on-going business learning (Ilhan-Nas et al., 2011). Third, our study extends the application of structure theory to immigrant entrepreneurship literature by addressing how cognitive cultural similarity enhances access to local tacit financial knowledge and tacit marketing knowledge characterised by contextualisation, embedding and ambiguity. While it has long been argued that the human capital and social capital of ethnic networks play a critical role in the adaptation processes of immigrant entrepreneurs in host countries (Kalnins \& Chung, 2006; Marger, 2001; Sequeira \& Rasheed, 2006), the way in which they specifically contribute to immigrant entrepreneurs' business learning has largely been ignored. Studies of the North American region, for example, assert that there is a directly positive effect of human capital over social capital on the earnings of Asian immigrant entrepreneurs (Marger, 2001; Valdez, 2008). Just how human capital and social capital exert roles in learning to achieve economic outcomes is given little explanation.

\section{THEORETICAL BACKGROUND AND HYPOTHESES}

\section{Human Capital and Tacit Knowledge Learning}

Entrepreneurs who own, launch, manage, and assume the risks of an economic venture (Greve \& Salaff, 2003) are at the centre of a firm's operation, including the acquisition of knowledge for its survival and growth (Lee \& Lan, 2011). Tacit marketing knowledge lies at the core of the sustainable competitive advantage enjoyed by successful entrepreneurs. It constructs the uniqueness of the firm's competences and knowledge pool, and these cannot be imitated easily by competitors. Tacit knowledge denotes "those connections among thoughts that cannot be pulled up in words, a knowing of what decision to make or how to do something that cannot be 
clearly voiced in a manner such that another person could extract and re-create that knowledge" (Bennet \& Bennet, 2008, p.5). The acquisition of tacit business knowledge therefore needs to be independent of conscious effort or overt activities that are cognition-intuitive, analytic and deliberative, and that require learning capabilities and supportive learning settings.

This study defines tacit financial knowledge as "know how" of the accounting skills, expertise in taxation and financial practices for business operations ( Millar \& Choi, 2009; De Boer et al., 1999; Widding, 2005). Immigrant entrepreneurs must utilise financial knowledge wisely with respect to investment, accounting and financing, in an environment in which they are operated and applied differently from in their home country. Tacit marketing knowledge is the know-how experiences and expertise in servicing, sales, pricing and promoting business (De Boer et al., 1999; Widding, 2005). Marketing knowledge is industry- and country-specific, and varies significantly across countries. Local tacit marketing knowledge is often difficult for immigrant entrepreneurs to acquire due to the inherent challenges in representing them in an unambiguous manner with strategic confidentiality (Lee \& Lan, 2011).

Human capital denotes the personal stock of competences, knowledge and personality attributes embodied in the ability to perform business-related activities (Kang \& Snell, 2009). High human capital, as a foundation for personal learning capabilities, enables immigrant entrepreneurs to engage in learning activities effectively, and serves as a base for intellectual resources. Context-generic human capital is a general learning capability and knowledge derived from formal education. Context-specific human capital denotes specific learning capabilities and knowledge derived from industrial experiences and skills (Madsen et al., 2003; Wang et al., 2009). Context-generic human capital supplies the intellectual basis for understanding general components of industrial knowledge; context-specific human capital allows for the articulation of local experiences and practices prior to internalisation (Bowman \& Swart, 2007). From a learning perspective, context-generic human capital is a catalyst to assist immigrant entrepreneurs recognise, absorb and transfer local tacit knowledge (Liao \& Welsch, 2005). According to the path dependence view, past education constrains an individual's learning capacities and restricts what is achievable, now and in the future (Ibrahim \& Galt, 2011).

Possession of fundamental knowledge eases the barriers to creative leaning, especially for acquiring tacit knowledge (Inkpen \& Tsang, 2005). Immigrant entrepreneurs with higher context-generic human capital are thus in a better position to understand and articulate financial practices in an effective manner than those without. Formal education, which improves personal cognition and enhances intellect, 
enables immigrant entrepreneurs to more efficiently exploit the existing tacit financial knowledge (Ley, 2006). Heath \& McMahon's (2000) empirical study proves the advantage that education brings to ethnic minorities from the Chinese and Indian communities in Britain, enabling them to reap the same occupational benefits as the non-immigrant population. In contrast, those from a West Indian or Pakistani background appear to be disadvantaged in the salaried labour market, and in selfemployment, due to an average lower level of education.

Tacit marketing knowledge includes the experiences of customer and competitor analysis, target-market analysis, as well as evaluation of any elements of the cultural and economic environment. Prior industry-specific experiences and training are likely to assist immigrant entrepreneurs to assimilate such local marketing experiences, and develop creative strategic initiatives. The attributes of cognitive and skill-based similarity enhance domains of learning, such as comprehension of facts and procedures, achieved through formal training, or informal processes of normative integration (Ilhan-Nas et al., 2011).

More specifically, prior industry-specific training provides a learning framework, which assists immigrant entrepreneurs to assimilate new specific local marketing knowledge through enabling them to search for relevant information from the right sources in the host country to improve their understanding and practices in marketing mechanisms (Bowman \& Swart, 2007); and rationally identify modifications to the marketing practices of the host county by integrating their previous training (Solomon et al., 2003). Indeed, it is argued that training for entrepreneurs contributes to their acquisition of essential knowledge (Hsu, 2007), and is thus critical for their success (Solomon et al., 2003).

Immigrant entrepreneurs' prior industry-specific experience is likely to play the role of a 'filter' in incorporating relevant tacit knowledge into the new business operation (Marvel \& Droege, 2010). These previous experiences increase the absorptive capability to exploit and transfer local marketing knowledge, as they enable deliberate associations to be made between past home country experiences and current business experiences, resulting in the forming of new insights (Solomon et al., 2003). The learning association is underpinned by the double-loop learning theory, which proposes that individuals have the ability to modify what they previously learnt in single-loop learning (Argyris \& Schon, 1978). Ilhan-Nas et al.'s study (2011) demonstrates that the ability of immigrant entrepreneurs to extract, synthesise and exploit marketing tacit knowledge is greatly influenced by their prior industry-related knowledge and experiences. Integrating the above analysis, we therefore hypothesise: 
Hypothesis 1: Immigrant entrepreneurs' formal education is positively related to their local tacit financial knowledge learning.

Hypothesis 2: Immigrant entrepreneurs' industry-related training is positively related to their local tacit marketing knowledge learning in the host country.

Hypothesis 3: Immigrant entrepreneurs' prior industry-specific experience is positively related to their local tacit marketing knowledge learning.

\section{Social Capital of Immigrant Entrepreneurs and Tacit Knowledge Learning}

\section{- Social Capital and Tacit Business Knowledge Learning}

Social capital consists of the relational resources embedded in networks characterised by norms of trust and reciprocity (Lechner et al., 2010). The essence of social capital is quality social relations facilitating collective actions for mutual benefits (Wever et al., 2005). As a key dimension of social capital, relational social capital is the trust-willingness to take initiatives (or risk) in a social context based on the assumption that others will respond as expected. Cognitive social capital consists of the social norms - the unwritten shared values and norms that direct behaviour and interactions (Nahapiet \& Ghoshal, 1998).

Tacit business knowledge is interdependent and non-codified knowledge that derives its meaning from its unique context (Reychav \& Weisberg, 2010). According to the structural theory which defines human life through relationships, learning activities are performed within a varying contextual structure. This is governed by a set of norms which are distinct from those of other social structures (Jack \& Anderson, 2002). Immigrant entrepreneurs' tacit knowledge learning is more seen as socially situated within the networks built in the local context of host countries, rather than in the isolated action of agents. The networks provide 'spaces' for immigrant entrepreneurs to undertake the interactive learning of tacit knowledge embedded in local ethnic intellectual resources (Greve \& Salaff, 2003; Anderson et al., 2010).

Cultivating trusting relationships and sharing a set of cultural values, norms and institutions, enables immigrant entrepreneurs to embed in their ethnic networks to maintain revolving flows of local knowledge (Stam \& Elfring, 2008), as well as to use the specifics of the environment to align and adapt new experiences . In this study, we concentrate on the relational and cognitive dimensions of social capital (Nahapiet \& Ghoshal, 1998), and base this on the premise that the field of immigrant entrepreneurship lacks empirical research on the effect of the interaction of social capital on business learning. 


\section{Relational Social Capital}

The relational dimension of social capital is concerned with the quality of interpersonal relationships among involved people (Nirmala \& Vemuri, 2009; Inkpen \& Tsang, 2005; Liao \& Welsch, 2005), and explicates how mutual trusting relationships work in reciprocal exchanges. Trustworthiness, in particular, is a core of relational social capital in entrepreneurship activities (Welter \& Smallbone, 2006). It is defined as confidence in the other party's reciprocal reliability, and risk-free conduct in exchange relationships (Molm et al., 2000). It is derived from an objective observation of another party's actions, and conclusive confidence in another person's competence and reputation. Previous research often tends not to distinguish trust and trustworthiness when addressing the social capital role in process-knowledge acquisition (Tsai \& Ghoshal, 1998). More recently, trustworthiness has received more scholarly attention and found to be positively related to interdependent actions (Kiyonari et al., 2006; Ploner, 2008). With trustworthiness, the truster confidently concludes that there is no risk in social exchanges on information, competencies, benevolence and integrity, with the targeted trustee (Molm et al., 2000; Colquitt \& Rodell, 2011). In comparison, trust only reflects a behavioural intention to be vulnerable, whereas trustworthiness reflects the immigrant entrepreneurs' positive attitudes toward other local entrepreneurs (Colquitt \& Rodell, 2011). The different facets of trustworthiness are viewed as currencies capable of fostering a social exchange.

There are several reasons for the leveraging role of trustworthiness in immigrant entrepreneurs' tacit knowledge learning. First, sharing experiences on marketing and financial strategies is voluntary, and with the trustworthiness developed through close connections in ethnic enclaves, immigrant entrepreneurs are likely to conclude that these people will provide reliable business experiences (De Carolis et al., 2009). Trustworthiness nurtures the ethnic members' bonding within networks, strengthens reciprocal relationships, and renders the individual vulnerable to others' actions of reciprocity (Inkpen \& Tsang, 2005; Wang \& Fulop, 2007; Anderson et al., 2010).

Second, struggling with an unfamiliar social environment in the host country, trustworthiness in ethnic communities minimises the immigrant entrepreneurs' perception of the risk of entering social exchanges for tacit knowledge (Nirmala \& Vemuri, 2009). Fear is a barrier to tacit knowledge sharing (Junni, 2007), particularly if no trustworthiness is embedded in relationships. Immigrant entrepreneurs may not be able to access local tacit business knowledge (Coleman, 1988) for fear that there will be no equitable value for return in exchanges, and they may lose competitive advantage if they share experiences of strategies (Wang et. al, 2009). Immigrant 
entrepreneurs tend to rely on ethnic social networks that they trust in for learning local business strategies rather than on communities in the host country where they feel excluded or discriminated against (Collins, 2003). Wever et al. (2005) found that family and friends from the same ethnic background are ranked as the most reliable sources of help by immigrants.

Third, in a perceived isolated environment, trustworthiness encourages immigrant entrepreneurs to extend the scope of close ties out from their trustworthy ethnic connections to a broader range of contacts in order to gain tacit finance and marketing knowledge (Rothengatter, 2005). We thus hypothesise:

Hypothesis 4: Immigrant entrepreneurs' belief in others' trustworthiness in ethnic enclaves is positively related to immigrant entrepreneurs' tacit marketing knowledge learning (Hypothesis 4a), and to their tacit financial knowledge learning (Hypothesis $4 b)$.

\section{Cognitive Social Capital}

Cognitive social capital refers to cultural similarity concerned with a common understanding through shared language, values, narratives, norms, and codes (Nahapiet \& Ghoshal, 1998; Nirmala \& Vemuri, 2009). Tacit business knowledge is characterised as intuitive, unspoken, intangible, and difficult to share, gain and absorb (Loebecke et al., 1999). It is integral to a person's consciousness, based on personal emotions, contextual experiences, intuition, observations and internalised information, and can only be transmitted via interpersonal interactions. Cognitive social capital determines the degree to which interacting individuals are similar in certain critical attributes such as beliefs, perceptions and values. Cognitive cultural similarities deepen the immigrant entrepreneurs' embeddedness in ethnic networks. This increases interactions for tacit knowledge learning as similarities create a context in which network members can engage and interact with each other easily and willingly (Liao \& Welsch, 2005; Nirmala \& Vemuri, 2009).

Feeling alienated by the cultural values, language and the behavioural codes of the mainstream society in the host country, immigrant entrepreneurs tend to resort to ethnic enclaves to learn context-specific business knowledge. Sometimes the barriers to learning tacit business knowledge from the mainstream are inevitable, due to the results of direct or institutional racism in the host countries (Ishaq et al., 2010).

Shared language and norms facilitate an ethnic individual's access to the embodied and symbolic forms of tacit business knowledge of the ethnic enclave by providing common references for observing, interpreting, and evaluating business information and experiences (Nonaka \& von Krogh, 2009; Nahapiet \& Ghoshal, 
1998). Shared cultural narratives expedite the transmission of business experiences through shared cultural myths, stories and metaphors among ethnic network connections. Shared cultural values involve the common preferences of the original culture leading to similar priorities being adopted for immigrant entrepreneurship. The shared values can engage network members in sharing the 'business secrets' of tacit knowledge business strategies and financial knowledge in the host country (Rothengatter, 2005). The following hypothesis is therefore proposed:

Hypothesis 5: Immigrant entrepreneurs' cognitive cultural similarity is positively related to tacit marketing knowledge learning (Hypothesis 5a) and tacit financial knowledge learning (Hypothesis 5b).

\section{METHODOLOGY}

\section{Sampling and procedure}

Thai and Chinese restaurant owners in Australia were chosen as the sample for our study. They are representative because they are a major ethnic immigrant group in Australia; as well as a mature group of immigrant entrepreneurs in terms of their business success in Australia (Research \& Statistics Section, 2007).

Self-administered questionnaires were distributed to a random sample of 843 restaurant owners drawn from a database of Thai-Australian restaurant owners held by the National Food Institute of Thailand in Australia and Chinese restaurant owners held by the Chinese Small Business Association. A total of 135 completed and useable questionnaires were returned, representing a response rate of $18 \%$. For reference, the average response rate in Western countries is $10 \%$. Follow-up calls were made to all potential respondents to minimise the risk of a poor response rate. The average response rate of the mailing survey in English-speaking Western countries ranges from $11 \%$ to $19 \%$ (Harzing, 1997). The response rate of our survey which took place in Australia reflected this trend, although the respondents were Thai and Chinese entrepreneurs. The demographic data are reported in Table 1. Most of the respondents had a bachelor's degree or higher. 
Table 1 Demographic Characteristics for Immigrant Entrepreneurs in Australia (Aus.)

\begin{tabular}{|c|c|c|c|c|c|}
\hline \multicolumn{6}{|l|}{ Variables: } \\
\hline \multirow[t]{2}{*}{ Gender } & \multicolumn{2}{|l|}{ Male } & \multicolumn{3}{|l|}{ Female } \\
\hline & $78(58.1 \%)$ & & $57(41.9 \%)$ & & \\
\hline \multirow[t]{2}{*}{ Age } & $25-29$ & $30-40$ & $41-50$ & Over 50 & \\
\hline & 0 & $39(38.8 \%)$ & $61(45 \%)$ & $\begin{array}{l}35 \\
(25.9 \%)\end{array}$ & \\
\hline \multirow[t]{3}{*}{ Education } & Primary & High & Diploma & Bachelor & Postgraduate \\
\hline & School & School & & & \\
\hline & $5(3.5 \%)$ & $15(11 \%)$ & $41(30.5 \%)$ & $\begin{array}{l}52 \\
(38.8 \%)\end{array}$ & $22(16.2 \%)$ \\
\hline \multirow[t]{2}{*}{$\begin{array}{l}\text { Length of time in } \\
\text { Aus. }\end{array}$} & $0-5$ years & $6-10$ years & 10-15 years & $\begin{array}{l}16-20 \\
\text { years }\end{array}$ & $\begin{array}{l}\text { Over } 20 \\
\text { years }\end{array}$ \\
\hline & $20(15 \%)$ & $27(20 \%)$ & $39(28 \%)$ & $35(25 \%)$ & $19(14)$ \\
\hline \multirow[t]{2}{*}{ Ownership years } & $0-5$ years & $6-10$ years & $10-15$ years & $\begin{array}{l}16-20 \\
\text { years }\end{array}$ & $\begin{array}{l}\text { Over } 20 \\
\text { years }\end{array}$ \\
\hline & $47(34 \%)$ & $39(28 \%)$ & $25(18.5 \%)$ & $15(11 \%)$ & $11(6.6 \%)$ \\
\hline $\mathrm{N}$ & 135 & & & & \\
\hline
\end{tabular}

\section{Measures}

All measures of independent variables used in the survey were either adopted or developed in accordance with the relevant literature. A five-point Likert scale $(1=$ 'strongly disagree' or 'very limited'; $5=$ 'strongly agree' or 'very rich') was used for responses, except for the formal education level variable.

\section{Dependent Variables}

Tacit financial knowledge (Cronbach's alpha $=0.74$ ) measured the extent to which the respondents learned how to deal with financial issues in the host country. By referring to Rath's (2010) explication of immigrant businesses related to finance operations, we developed a scale of tacit financial knowledge. The scale of this variable was composed of three items: being able to obtain information on how to find a lender and obtaining a loan for business, handle accounting matters, and deal with local taxation matters.

Tacit marketing knowledge (Cronbach's alpha $=0.84)$ measured the 'know-how' to operate and organise marketing in the host country market. We referred to Simonin's (1999) measure of learning tacit marking knowledge and the scale of this variable was modified as follows: the ability to learn marketing skills and know-how to:(i) advertise effectively; (ii) meet local customers' expectations; (iii) comply with local marketing regulations; (iv) decorate business premises appropriately; and (v) produce suitable products. 


\section{Independent Variables}

Human capital was evaluated with three scales based on the proxy principles for human capital by Hitt et al. (2001) and modified from Gelderen et al.'s study (2006). To assess their formal education, we ranked three level from primary school to postgraduate education to measure context-generic human capital (Lee \& Tsang, 2001; Madsen et al., 2003). Context-specific human capital of prior specific-industry experiences was measured by a scale composed of working years in a similar industry before the current business, and working years in the same industry before starting the current business (Cronbach's alpha $=0.72$ ) (Gelderen et al., 2006). The industryrelated training was measured with a scale of training hours in the home country and the host country (Cronbach's alpha $=0.73$ ).

Relational social capital was measured by a dimension of trustworthiness. Trustworthiness (Cronbach's alpha $=0.92$ ) was measured by the extent to which the respondents had confidence that they would be reciprocated with reliability and experience risk-free conduct by other party in the exchange relationships. The measure is adapted from Molm et al.'s measurement framework (2000) and composed four items - whether the respondents were confident that they would get help from close connections within their relatives and their friends, and whether these contacts were: (i) reliable; (ii) useful; (iii) genuine; and (iv) valuable.

Cognitive social capital (Cronbach's alpha $=0.84$ ) was adopted from Liao \& Welsch's study (2005) measuring the extent of cognitive cultural similarity. The measure was composed of five items on business connections and sharing. It measures whether these connections: (i) were of the same nationality; (ii) were the same cultural background; (iii) were with a similar business background in the host country; (iv) had a similar view of success and failure in life; and (v) had similar ways of doing things.

\section{Control Variables}

In the analysis, we controlled for the age of the respondents and the duration of ownership, both of which have an effect on entrepreneurial behaviour related to business experiences (Davidsson \& Honig, 2003). We also controlled for the existence length and the size of a firm, because these affect the resources available to an entrepreneur (Premaratne, 2001).

\section{Validity and Analysis}

Several steps were taken to ensure validity of measurement. First, the original items of the questionnaire were translated from English to Thai. Equivalence between the Thai and English versions was ensured through backwards-forwards translation. A 
pilot study was conducted with Thai-speaking postgraduate students to check content and face validity. The Chinese questionnaire was also ensured that the meaning was translated precisely through backwards-forwards translation.

Second, to ensure face and content validity, a second pilot study was conducted with restaurant owners. Finally, we applied exploratory factor analysis (EFA), identifying the structure of a set of observed variables, and then confirmatory factor analysis (CFA) to ensure 1) the internal convergent validity within each construct and the concurrent validity, 2) discriminant validity between the constructs, and 3) the validity of the scale of tacit financial knowledge developed in this study. The results of the EFA and CFA ensure that there is no common method bias in forming the scales and analysis of multiple regressions in our study. We tested the hypotheses with bivariate correlation analysis and multiple regressions.

\section{Correlation and Reliability}

\section{RESULTS}

The means, standard deviations, and Pearson correlations for the demographic and other variables are presented in Table 3. The average age of the respondents was 43.92 years old with a standard deviation of 7.48. Most of the respondents had a bachelor's degree or higher. In terms of relations among variables, the results revealed that the variables 'industry training' $(r=0.39, p<0.01)$ and 'trustworthiness' $(r=$ $0.51, p<0.01)$ had significant correlations with 'marketing knowledge learning'. Three variables including 'industry training' $(r=0.40, p<0.01)$, 'trustworthiness' ( $r=$ $0.54, p<0.01)$, and 'cultural cognition similarity' $(r=0.36, p<0.01)$ had significant correlations with 'acquisition of financial knowledge'.

\section{Hypothesis Testing}

The hypotheses were tested using multiple regression analysis. The results in Table 2 reveal that human capital was strongly related to an immigrant entrepreneur's tacit knowledge learning. There was a significant positive relationship between 'formal education' and 'learning of tacit financial knowledge' $(\beta=0.28, p<0.05)$. Industry-related training was related to tacit marketing knowledge learning $(\beta=0.25$, $p<0.05$ ). These findings provide support for Hypothesis 1 , which argued for a positive relationship between formal education and the acquisition of marketing knowledge, and Hypothesis 2, which posited a positive relationship between industryrelated training and the acquisition of marketing knowledge. 'Prior industry-specific experience' was also found to have a significant relationship with tacit marketing knowledge $(\beta=0.24, p<0.05)$, supporting Hypothesis 3 . 
With regard to the scale of 'relational social capital', trustworthiness is shown to have a significant positive effect on learning tacit marketing knowledge $(\beta=0.48, p<0.01)$ and financial knowledge $(\beta=0.29, p<0.05)$. Hypothesis $4 \mathrm{a}$ and Hypothesis $4 \mathrm{~b}$ are thus supported. Finally, no significant relationship was found between 'cultural cognition similarity' and tacit financial knowledge, but a significant relationship between cultural cognition similarity and tacit marking knowledge $(\beta=0.20, p<0.05)$ is shown. Hypothesis $5 \mathrm{a}$ is therefore supported and Hypothesis $5 \mathrm{~b}$ rejected. A summary of the results of the tested hypotheses is presented in Table 4.

Table 2 Means, Standard Deviations and Pearson Correlations of Human Capital, Social Capital and Business Learning

\begin{tabular}{|c|c|c|c|c|c|c|c|c|c|c|c|c|c|c|}
\hline & Mean & S.D. & 1 & 2 & 3 & 4 & 5 & 6 & 7 & 8 & 9 & 10 & 11 & 12 \\
\hline 1. Owner age ${ }^{a}$ & 43.92 & 7.48 & - & & & & & & & & & & & \\
\hline 2. Ownership $\mathrm{yr}^{\mathrm{b}}$ & 9.17 & 6.19 & $.51^{* *}$ & - & & & & & & & & & & \\
\hline 3. Firm length ${ }^{c}$ & 7.85 & 5.30 & .14 & $.40^{* *}$ & - & & & & & & & & & \\
\hline 4. Firm size ${ }^{d}$ & 6.72 & 3.79 & -.01 & .18 & .19 & - & & & & & & & & \\
\hline 5. Education ${ }^{\mathrm{e}}$ & 3.52 & 0.96 & $-.38 * *$ & -.13 & .10 & .06 & - & & & & & & & \\
\hline 6. Training & 3.01 & 1.27 & .01 & .05 & .01 & .18 & -.12 & - & & & & & & \\
\hline $\begin{array}{l}\text { 7. Industry } \\
\text { Experience }\end{array}$ & 3.82 & 1.20 & -.18 & -.20 & $-.25^{*}$ & -.02 & $-.23^{*}$ & $.52 * *$ & - & & & & & \\
\hline 8. Trustworthiness & 2.85 & .99 & $-.25^{*}$ & -.06 & .14 & $.27 *$ & $.29 * *$ & $.23^{*}$ & .16 & & & & & \\
\hline 10. $\operatorname{CSC}^{\mathrm{f}}$ & 4.01 & .94 & -.12 & .00 & -.05 & .19 & $.34 * *$ & .11 & .05 & $.29 *$ & $.49 * *$ & - & & \\
\hline 11. Mkt K ${ }^{\mathrm{g}}$ & 3.11 & .92 & -.09 & .01 & .09 & $.41^{* *}$ & .21 & $.39^{* *}$ & $.38^{*}$ & $51^{* *}$ & $.38 * *$ & $.23^{*}$ & - & \\
\hline 12. Fin $\mathrm{K}^{\mathrm{h}}$ & 3.20 & 1.00 & $-.28^{*}$ & -.09 & .03 & .19 & .16 & $.40^{* *}$ & .17 & $54^{* *}$ & $.36^{* *}$ & $.37^{* *}$ & $.55^{* *}$ & - \\
\hline $\begin{array}{l}\text { ** } \mathrm{p} \leq 0.01 \text { level (two } \\
{ }^{\mathrm{a}} \text { Owner age is presen } \\
{ }^{\mathrm{b}} \text { Ownership length is } \\
{ }^{\mathrm{C}} \text { Restaurant age is the } \\
{ }^{\mathrm{d}} \text { Firm size is determi } \\
{ }^{\mathrm{C}} \text { Education level is co } \\
{ }^{\mathrm{f}} \text { CCS stands for cogn } \\
{ }^{\mathrm{g}} \text { Mkt K stands for ma } \\
{ }^{\mathrm{h}} \text { Fin K stands for fina }\end{array}$ & $\begin{array}{l}d) \cdot{ }^{*} \\
\text { yearly } \\
\text { ength o } \\
\text { ational } \\
\text { y the av } \\
\text { s } 1=p \\
\text { cultural } \\
\text { ng kno }\end{array}$ & $\begin{array}{l}\leq 0.051 \\
\text { units. } \\
\text { f busine } \\
\text { length } \\
\text { engene } n \\
\text { rimary } \\
\text { similar } \\
\text { vledoe }\end{array}$ & $\begin{array}{l}\text { evel (two- } \\
\text { ss owners } \\
\text { of the rest } \\
\text { umber of } \\
\text { school; } 2 \\
\text { ity. }\end{array}$ & $\begin{array}{l}\text {-tailed). } \\
\text { ship, and } \\
\text { taurant a } \\
\text { staff. } \\
=\text { seconc } \\
\text { n. }\end{array}$ & $\begin{array}{l}\text { pres } \\
\text { pres } \\
\text { ry sc }\end{array}$ & $\begin{array}{l}\text { ed in ye } \\
\text { ed in ye }\end{array}$ & $\begin{array}{l}\text { early } \\
\text { early } \\
\text { diplom }\end{array}$ & $=\mathrm{ba}$ & 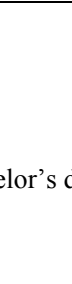 & 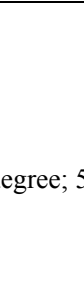 & 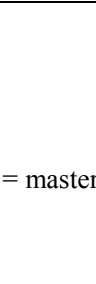 & deg & & \\
\hline
\end{tabular}


Table 3 Results of Multiple Regressions for Tacit Business Learning for Immigrant Entrepreneurs on Human Capital and Social Capital in Australia

\begin{tabular}{|c|c|c|c|c|c|c|}
\hline \multirow[t]{2}{*}{ Variables: } & \multicolumn{3}{|c|}{ Tacit Marketing Knowledge } & \multicolumn{3}{|c|}{ Tacit Financial Knowledge } \\
\hline & Model 1 & Model 2 & Model 3 & Model 1 & Model 2 & Model 3 \\
\hline \multicolumn{7}{|l|}{ Control variables: } \\
\hline Owner age ${ }^{a}$ & $-.23^{+}$ & -.11 & -.08 & -.07 & .11 & .14 \\
\hline Ownership years ${ }^{b}$ & -.02 & -.05 & -.05 & -.04 & -.07 & -.08 \\
\hline Firm length ${ }^{\mathrm{c}}$ & .04 & -.03 & -.03 & .06 & .03 & .02 \\
\hline Firm size ${ }^{\mathrm{d}}$ & $.18^{+}$ & -.09 & -.00 & $.38 * *$ & $.25 * *$ & $.23 * *$ \\
\hline \multicolumn{7}{|l|}{ Main effects } \\
\hline \multicolumn{7}{|l|}{ Human capital } \\
\hline Formal education ${ }^{\mathrm{e}}$ & & -.03 & -.06 & & $.28^{*}$ & $.31 *$ \\
\hline Industry training & & $.25 *$ & $.27 *$ & & .10 & .18 \\
\hline $\begin{array}{l}\text { Industry-related } \\
\text { experience }\end{array}$ & & $.23^{*}$ & $.24 *$ & & .01 & .05 \\
\hline \multicolumn{7}{|l|}{ Social capital } \\
\hline Trustworthiness & & & $.48 * *$ & & & $.29 *$ \\
\hline $\mathrm{CSC}^{\mathrm{f}}$ & & & $.20 *$ & & & -.11 \\
\hline $\mathrm{R}^{2}$ & .28 & .36 & .49 & .13 & .28 & .36 \\
\hline Adjusted $\mathrm{R}^{2}$ & .05 & .37 & .37 & .08 & .15 & .27 \\
\hline $\mathrm{F}$ & 3.02 & $4.90 *$ & $6.10 * *$ & $3.02 *$ & $3.85 * *$ & $4.25 * *$ \\
\hline $\mathrm{N}$ & 135 & 135 & 135 & 135 & 135 & 135 \\
\hline
\end{tabular}

$* \mathrm{p} \leq .05 ; * * \mathrm{p} \leq .01$

${ }^{\mathrm{a}}$ Owner age is presented in yearly units.

${ }^{\mathrm{b}}$ Ownership years is the length of business ownership experience and presented in yearly units

${ }^{\mathrm{c}}$ Firm length is the operational length of the restaurant and presented in yearly units.

${ }^{\mathrm{d}}$ Firm size is determined by the average number of staff.

${ }^{\mathrm{e}}$ Education level is coded as $1=$ primary school; 2 = secondary school; $3=$ diploma; $4=$ bachelor's degree; $5=$ master's degree.

${ }^{\mathrm{f}} \mathrm{CCS}$ stands for 'cultural cognitive similarity'.

Table 4. Summary of hypotheses and findings for immigrant entrepreneurs in tacit knowledge learning

\begin{tabular}{|c|c|c|}
\hline Ordeı & Hypothesis Statement & Significance \\
\hline H1 & $\begin{array}{l}\text { Immigrant entrepreneurs' formal education of human capital is positively related to their } \\
\text { tacit financial knowledge learning. }\end{array}$ & YES+* \\
\hline $\mathrm{H} 2$ & $\begin{array}{l}\text { Immigrant entrepreneurs' industry-related training is positively related to their tacit } \\
\text { marketing knowledge learning in the host country. }\end{array}$ & YES +* \\
\hline $\mathrm{H} 3$ & $\begin{array}{l}\text { Immigrant entrepreneurs' prior industry-specific experience is positively related to their } \\
\text { tacit marketing knowledge learning. }\end{array}$ & YES+* \\
\hline $\mathrm{H} 4 \mathrm{a}$ & $\begin{array}{l}\text { Immigrant entrepreneurs' belief in other's trustworthiness in ethnic enclaves is } \\
\text { positively related to their tacit marketing knowledge learning. }\end{array}$ & YES +** \\
\hline $\mathrm{H} 4 \mathrm{~b}$ & $\begin{array}{l}\text { Immigrant entrepreneurs' belief in other's trustworthiness in ethnic enclaves is positively } \\
\text { related to their tacit financial knowledge learning }\end{array}$ & YES+* \\
\hline H5a & $\begin{array}{l}\text { Immigrant entrepreneurs' cognitive cultural similarity is positively related to their tacit } \\
\text { marketing knowledge learning. }\end{array}$ & YES +* \\
\hline $\mathrm{H} 5 \mathrm{~b}$ & $\begin{array}{l}\text { Immigrant entrepreneurs' cognitive cultural similarity is positively related to their tacit } \\
\text { financial knowledge learning. }\end{array}$ & NO \\
\hline
\end{tabular}




\section{DISCUSSION}

The rationale of our study is to respond to the recent call for more research on the under-explored area of the determinants stimulating or hampering immigrant entrepreneurship. The study examines the previously neglected area of the business learning of immigrant entrepreneurs in the host country. Therefore, we see a number of contributions to the entrepreneurship literature.

\section{Theoretical Implications}

Entrepreneurship 'is always already multiple, diverse, and distributed, recursively being constituted within specific settings and milieus' (Styhre, 2008, p. 103). It is critical, therefore, to understand how immigrant entrepreneurs' tacit business knowledge learning takes place in the host country which presents many inherent constraints for them.

First, our study contributes to the immigrant entrepreneurship literature by explicating the learning facilitative effect of social capital, as well as the learning capability effect of context-related human capital on immigrant entrepreneurs' business learning. We conclude that human capital and social capital play a complementary role in immigrant entrepreneurs' business learning in assimilating into unfavourable institutional environments. The results fill an analytical gap in the literature which does not explain why some immigrant groups are more successful in entrepreneurship than others with a similar level of human capital (e.g. Marger, 2001; Valdez, 2008).

Our analysis also extends the previous view that context-generic human capital provides only background knowledge for an awareness of new experiences (e.g. Premaratne, 2001). The findings suggest that formal education plays a role in learning capability by engendering immigrant entrepreneurs to develop a better understanding of new tacit financial experiences, and articulation of accounting with local practices.

Furthermore, our study extends previous research on the relationship between industry training and entrepreneurs' knowledge (e.g. Hsu, 2007). The study establishes that industry-related training and prior industry-specific experience enable immigrant entrepreneurs to recognise and absorb tacit local marketing knowledge in a particular industry. Industry-related training provides the immigrant entrepreneurs not only with basic operational skills but also with a specific learning framework through which they can ascertain the knowledge needed to initiate marketing strategies successfully in a host country. Prior industry-specific experience can strengthen their absorptive capability to transfer local marketing knowledge to develop new insights. 
Previous studies have not focused on the impact of ethnic social capital on the business learning of immigrant entrepreneurs, and concentrate only on its role in sharing information about business opportunities and financial resources (e.g., Chand \& Ghorbani, 2011; Ibrahim \& Galt, 2011). Our study contributes to the entrepreneurship literature by explaining the facilitative role of relational and cognitive capital in immigrant entrepreneurs' learning. Apart from the disadvantages faced in the host country, local tacit knowledge is contextualised, specific and ambiguous and an inherent fear of opportunism in its transfer can be amplified by immigrant entrepreneurs. Our findings suggest that a way to overcome these constraints in learning tacit business knowledge is for immigrant entrepreneurs to choose to strengthen their level of embeddedness within local networks to increase interactions through relational and cognitive social capital.

By addressing the facilitative role of social capital in cultivating the willingness to reveal, share and demonstrate tacit business knowledge among ethnic connections, we extend previous studies which focus on the quantity of social capital, such as network density, frequency and size in the learning context of the host country. Cultivation of trustworthy relationships and cognitive cultural similarities in ethnic communities create active exchanges embedded in ethnic networks for tacit marketing knowledge learning. Trustworthiness embedded in ethnic enclaves encourages immigrant entrepreneurs to proactively participate and reciprocate for learning purposes. Cognitive cultural similarity assists them to share, and make sense of, local business tacit knowledge within ethnic communities. High cognitive cultural similarity and trustworthiness can lessen the likelihood of entrepreneurs in the immigrant community wanting to preserve the confidentiality of sensitive business information, and ease the 'stickiness' of the transmission of embodied tacit forms of knowledge by basing learning activities on an affinity of shared emotions, narratives, values and perceptions.

\section{Managerial Implications}

Based on our findings, we suggest that those immigrant entrepreneurs who are weak in human capital should actively cultivate and extend their relational and cognitive social capital through embedding in ethnic networks to gain tacit marketing knowledge. Highly developed relational and cognitive social capital, embedded in ethnic networks, can compensate for this lack of human capital, and for difficulties encountered in sharing tacit business knowledge in host countries.

To start a successful business in a host country, immigrant entrepreneurs should participate in the industry training programs provided by both host and home 
countries. Immigrants arrive in their host countries with differing levels of human capital. Those arriving with more context-generic human capital will adapt to the new business environment faster than immigrants with less. Immigration policy-makers, therefore, should make regulations which attract immigrants with high level human capital, and provide the industry-specific training necessary to ensure the immigrants' contribution to national economies.

\section{Limitations and Future Research}

While our research is one of only a handful of empirical studies that explore the tacit knowledge learning of immigrant entrepreneurs, several limitations provide opportunities for further research. First, generalisation of the findings should be taken with caution because the study examines only one ethnic group of entrepreneurs. Further research could extend the investigation to other ethnic groups, in other host countries and industry settings.

In addition, the present study also could not comprehensively address all the factors related to the tacit knowledge acquisition of immigrant entrepreneurs. The processes of tacit knowledge acquisition are more complex than are shown in this report. For example, a third aspect of social capital, structural social capital (Davidsson \& Honig, 2003), was not included in the present study. Future research could extend the scope of the present study to include a wider variety of dynamic factors.

Finally, with regard to the control variables, the industry type is not included in the study, as the targeted industry was solely focused on the food service industry. The length of stay of immigrant entrepreneurs in the host country is also not included in the analysis of regression we reported. The justification for this exclusion is that tacit business knowledge learning is not affected by the length of stay if the immigrant's self-employed business is not established for the whole duration. Moreover, the respondent may be a second-generation immigrant born in the host country. Research in the future, however, may test the effect of both factors as control variables.

\section{Conclusions}

Our study contributes to the literature of entrepreneurship by exploring the business learning of immigrant entrepreneurs in a host country. This is traditionally an area which has received little scholarly attention. The findings of our study elucidate the complex interaction between tacit business knowledge, and the social and human capital of immigrant entrepreneurs. Recognising the contextualisation, embedding, and ambiguity of tacit knowledge, we conclude that immigrant entrepreneurs' learning 
capabilities of context-related human capital and learning facilitation of social capital play a critical part in their tacit marketing and financial knowledge acquisition. The endogenous and exogenous learning factors and process of immigrant entrepreneurs involve dynamic interactions and complexity and can act powerfully to foster success. The outcome of our study, an initial step in this area, is an improved understanding of the business creation, and growth, of the firms of immigrant entrepreneurs in host countries. We hope our article stimulates future research on this complicated but important issue.

\section{REFERENCES}

Anderson, A.R., Dodd, S.D. and Jack S. (2010). Network practices and entrepreneurial growth, Scandinavian Journal of Management, 25(2), 121-133. http://dx.doi.org/10.1016/j.scaman.2010.01.005

Argyris, C., \& Schon, D. (1978). Organizational learning. Reading, MA: AddisonWesley.

Bennet, D. and Bennet, A. (2008). Engaging tacit knowledge in support of organizational learning, Vine, 38(1), 1-25. http://dx.doi.org/10.1108/03055720810870905

Bowman, C. \& Swart, J. (2007). Whose human capital? The challenge of value capital when challenge is embedded. Journal of Management Studies, 44(4), 488-505. http://dx.doi.org/10.1111/j.1467-6486.2006.00635.x

Chand, M. and Ghorbani, M., (2011). National culture, networks and ethnic entrepreneurship: A comparison of the Indian and Chinese immigrants in the US, International Business Review, 20, 593-606. http://dx.doi.org/10.1016/j.ibusrev.2011.02.009

Coleman, J. S. (1988). Social capital in the creation of human capital, American Journal of Sociology, 94, 95-120. http://dx.doi.org/10.1086/228943

Collins, J. (2003). Cultural diversity and entrepreneurship: policy responses to immigrant entrepreneurs in Australia, Entrepreneurship \& Regional Development, 15, 137-149. http://dx.doi.org/10.1080/0898562032000075168

Colquitt, J. A. and Rodell, J. B. (2011). Justice, trust, and trustworthiness: A longitudinal analysis integrating three theoretical perspectives. Academy of Management Journal, 54, 1183-1206.

Cranefield, J. (2009). Online Communities of Practice and Professional Change: A ThreeTier View of the Knowledge Embedding process, $P h D$ thesis. Retrieved from http://researcharchive.vuw.ac.nz/bitstream/handle/10063/1147/thesis.pdf.txt?sequence $=5$ 
Cranefield, J. (2009) . Online Communities of Practice and Professional Change: A Three-Tier View of the Knowledge Embedding process, Doctor of Philosophy in Information Systems, http://researcharchive.vuw.ac.nz/bitstream/handle/10063/1147/thesis.pdf.txt?sequ ence $=5$

Davidsson, P. and Honig, B. (2003). The role of social and human capital among nascent entrepreneurs, Journal of Business Venturing, 18(3), 301-331. http://dx.doi.org/10.1016/S0883-9026(02)00097-6

De Boer, M., Van Den Bosch, F. A. J. and Volberda, H. W. (1999). Managing organizational knowledge integration in the emerging multimedia complex, Journal of Management Studies, 36 (3) , 379-395. http://dx.doi.org/10.1111/1467-6486.00141

De Carolis, D. M., Litzky, B. E. and Eddleston, K. A. (2009). Why networks enhance the progress of new venture creation: the influence of social capital and cognition, Entrepreneurship: Theory \& Practice, 33 (2): 527-545. http://dx.doi.org/10.1111/j.1540-6520.2009.00302.x

Gelderen, M. V., Thurik, R. and Bosma, N. (2006) Success and risk factors in the prestart-up phase. Small Business Economics, 26 (4): 365-380.

Greve, A. and Salaff, J. W. (2003). Social networks and entrepreneurship, Entrepreneurship Theory and Practice, 28 (1): 1-22. http://dx.doi.org/10.1111/1540-8520.00029

Harzing, A.W. (1997) Response rates in international mail surveys: Results of a 22 country study, International Business Review, vol. 6, no. 6, pp. 641-665. http://dx.doi.org/10.1016/S0969-5931(97)00040-1

Heath, A., \& McMahon, D. (2000). Ethnic differences in the labour market: The role of education and social class origins. Working paper. Department of Sociology, University of Oxford.

Hitt, M.A., Bierman, L., Shimizu, K., and Kochhar, R. (2001). Direct and indirect effects of human capital on strategy and performance in professional service firms: a resource-based perspective. Academy of Management Journal, 44: 1, 1328.

Hsu, D. H. (2007). Experienced entrepreneurial founders, organizational capital, and venture capital funding, Research Policy, 36 (5), 722-741. http://dx.doi.org/10.1016/j.respol.2007.02.022

Ibrahim, G., and Galt, V. (2011), Explaining ethnic entrepreneurship: An evolutionary economics approach, International Business Review, 20, 607-613 http://dx.doi.org/10.1016/j.ibusrev.2011.02.010 
Ilhan-Nas, T., Sahin, K., Cilingir, Z. (2011). International ethnic entrepreneurship: Antecedents, outcomes and environmental context, International Business Review, 20, 614-626. http://dx.doi.org/10.1016/j.ibusrev.2011.02.011

Inkpen, A. C. and Tsang, E. W. K. (2005). Social capital, networks, and knowledge transfer, Academy of Management Review, 30 (1), 146-165. http://dx.doi.org/10.5465/AMR.2005.15281445

Ishaq, M. Hussain, A., Whittam, G. (2010) Racism: A barrier to entry? Experiences of small ethnic minority retail businesses. International Small Business Journal 28(4), 362-377. http://dx.doi.org/10.1177/0266242610363523

Jack, S., and Anderson, A.R. (2002). The effects of embeddedness upon the entrepreneurial process. Journal of Business Venturing, 17(5), 467-487.

Kalnins, A. And Chung, W. (2006). Social capital, Geography, and survival: Gujarati immigrant entrepreneurs in the U.S. lodging industry. Management Science, 52 (2), 233-247. http://dx.doi.org/10.1287/mnsc. 1050.0481

Kang, S. and Snell, S. A. (2009) . Intellectual capital architectures and ambidextrous learning: a framework for human resource management, Journal of Management Studies, 46 (1), 65-92. http://dx.doi.org/10.1111/j.1467-6486.2008.00776.x

Kiyonari, T. Yamagishi, T., Cook K. and Cheshire, C., (2006). Does Trust Beget Trustworthiness? Trust and trustworthiness in two games and two cultures: A research note, Social psychology quarterly, 69 (3), 270-283 http://dx.doi.org/10.1177/019027250606900304

Lechner, C., Frankenberger, K. and Floyd, S. W. (2010). Task Contingencies in the Curvilinear Relationship between Intergroup Networks and Initiative Performance, Academy of Management Journal, 53 (4), 865-889. http://dx.doi.org/10.5465/AMJ.2010.52814620

Lee, D. Y. and Tsang, E. W. K. (2001). The effect of entrepreneurial personality background and network activities on venture growth, Journal of Management Studies, 38 (4), 583-602. http://dx.doi.org/10.1111/1467-6486.00250

Ley, D. (2006), Explaining variations in business performance among immigrant entrepreneurs in Canada, Journal of Ethnic and Migration Studies, 32 (5), 743 764. http://dx.doi.org/10.1080/13691830600704123

Lee, M.R. and Lan, Y. (2011). Toward a unified knowledge management model for SMEs, Expert Systems with Applications, 8 (1), 729-735. http://dx.doi.org/10.1016/j.eswa.2010.07.025

Liao, J. and Welsch, H. (2005). Roles of social capital in venture creation: key dimensions and research implications, Journal of Small Business Management, 43 (4), 345-362. http://dx.doi.org/10.1111/j.1540-627X.2005.00141.x 
Loebecke, C., Van Fenema, P. C., \& Powell, P., (1999). Information Systems, 30 (2), 14-25.

Junni, P. (2007). Knowledge transfer in mergers and acquisitions - the roles of fear of exploitation and contamination. Paper presented at the Knowledge Transfer in Mergers and Acquisitions, Beyond Waltz - Dances of Individuals and Organization, 23rd EGOS Colloquium 2007, in Vienna, Austria.

Madsen, H., Neergaard, H.and Ulhoi, J. P. (2003). Knowledge-intensive entrepreneurship and human capital, Journal of Small Business and Enterprise Development, 10 (4), 426-434. http://dx.doi.org/10.1108/14626000310504738

Marger, M. N. (2001). Social and human capital in immigrant adaptation: the case of Canadian business immigrants, Journal of Socio-Economics, 30 (2), 169-170.

Martens, M. L., Jennings, J. E. and Jennings, P. D. (2007). Do the stories they tell get them the money they need? The role of entrepreneurial narratives in resource acquisition, Academy of Management Journal, 50 (5), 1107-1132. http://dx.doi.org/10.5465/AMJ.2007.27169488

Marvel, M. R. and Droege, S. (2010). Prior tacit knowledge and first-year sales: learning from technology entrepreneurs, Journal of Small Business and $\begin{array}{llll}\text { Enterprise } & \text { Development, } & 17 & \text { (32), }\end{array}$ http://dx.doi.org/10.1108/14626001011019116

Millar, C. and Choi, C. (2009). Networks, Social Norms and Knowledge SubNetworks, Journal of Business Ethics, Supplement 4 (90), 565-574. http://dx.doi.org/10.1007/s10551-010-0607-x

Molm, LD. Takahashi, Peterson, N G, (2000). Risk and trust in social exchange: An experimental test of a classical proposition, American Journal of Sociology, 105(5),1396-1427. http://dx.doi.org/10.1086/210434

Nahapiet, J.and Ghoshal, S. (1998) Social capital, intellectual capital, and the organizational advantage, The Academy of Management Review, 23, 2, 242-266.

Nirmala, M. and Vemuri, M. (2009). Leveraging informal networks in knowledge management, Journal of Knowledge Management, 13(3), 146-156. http://dx.doi.org/10.1108/13673270910962932

Nonaka, I. (1994). A Dynamic Theory of Organizational Knowledge Creation, Organization Science, 5 (1), 14-37. http://dx.doi.org/10.1016/B978-0-7506-71118.50003-2

Nonaka, I. and von Krogh, K. (2009). Tacit Knowledge and Knowledge Conversion: Controversy and Advancement in Organizational Knowledge Creation Theory, Organization Science, 20 (3), 635-652. http://dx.doi.org/10.1287/orsc.1080.0412 
Ploner, M., (2008). The impact of payoff interdependence on trust and trustworthiness, German Economic Review, 9 (1), 87-95.

Premaratne, S. P. (2001). Networks, resources, and small business growth: the experience in Sri Lanka, Journal of Small Business Management, 39 (4), 363371. http://dx.doi.org/10.1111/0447-2778.00033

Rath, J., (2010). Ethnic entrepreneurship of the report, European Foundation for the Improvement of Living and Working Conditions.

Reychav, R and Weisberg, I., (2010). Bridging intention and behavior of knowledge sharing, Journal of Knowledge Management, 14 (2), 285-300. http://dx.doi.org/10.1108/13673271011032418

Rothengatter, M. R (2005). Social networks and tax (non-)compliance in a multicultural nation: Emerging themes from a focus-group study among ethnic minorities in Australia, International Journal of Entrepreneurial Behaviour \& Research, 11(4), 280-314. http://dx.doi.org/10.1108/13552550510603306

Research and Statistics Sections, Immigration Update July-December (2007). http://www.immi.gov.au/media/publications/pdf/Update_Dec06.pdf.

Sequeira, J. M.and Rasheed, A. A. (2006). Start-up and growth of immigrant small businesses: the impact of social and human capital, Journal of Developmental Entrepreneurship, 11(4), 357-375. http://dx.doi.org/10.1142/S1084946706000490

Simonin, B. L. (1999). Transfer of Marketing Know-How in International Strategic Alliances: An Empirical Investigation of the Role and Antecedents of Knowledge Ambiguity. Journal of International Business Studies, 30(3), 463-490. http://dx.doi.org/10.1057/palgrave.jibs.8490079

Solomon, G., Fernald, Jr L. W. and Dennis, W. (2003). Self-identified management deficiencies of entrepreneurs, The Journal of Private Equity, Winter, 26-35. http://dx.doi.org/10.3905/jpe.2003.320062

Stam, W. and Elfring, T. (2008)., Entrepreneurial orientation and new venture performance: the moderating role of intra- and extraindustry social capital, Academy of Management Journal, 51(1), 97-111. http://dx.doi.org/10.5465/AMJ.2008.30744031

Styhre, A. (2008). Transduction and entrepreneurship: A biophilosophical image of the entrepreneur. Scandinavian Journal of Management, 24 (2), 103-112. http://dx.doi.org/10.1016/j.scaman.2008.03.004

Tsai, W. \& Ghoshal, S. (1998). Social capital and value creation: The role of intrafirm networks, Academy of Management Journal, 41(4), 464-476 http://dx.doi.org/10.2307/257085 
Valdez, Zulema. (2008).The effect of social capital on white, Korean, Mexican and black business owners' earnings in the US, Journal of Ethnic and Migration Studies, 4 (6), 955-973.

Wang, K. Y. and Fulop L. (2007). Managerial trust and work values within the context of international joint ventures in China, Journal of International Management, 13 (2), 164-186. http://dx.doi.org/10.1016/j.intman.2006.11.001

Wang, K. Y., Li-Hua, R and Xu, E.M, (2009). Acquisition of tacit marketing knowledge: A role of human capital and social capital of entrepreneurs in China, Journal of Chinese Entrepreneurship, 1 (2), 103-120. http://dx.doi.org/10.1108/17561390910956279

Wang, K. Y. Wang, Y., Huang, K. P., and Deng, JS. (2011). Heterogeneous networks and resource acquisition of SMEs in emerging economies, Quality \& Quantity, International Journal of Methodology. http://dx.doi.org/10.1007/s11135-0119472-7.

Welter, F. and Smallbone, D. (2006). Exploring the role of trust in entrepreneurial activity, Entrepreneurship: Theory and Practice, July, 465-475. http://dx.doi.org/10.1111/j.1540-6520.2006.00130.x

Wever, S. D., Martens, R. and Vandenbempt, K. (2005). The impact of trust on strategic resource acquisition through interorganizational networks: towards a conceptual model, Human Relations, 58 (12), 1523-1544.

Widding, L. O. (2005). Building entrepreneurial knowledge reservoirs. Journal of Small Business and Enterprise Development, 12 (4), 595-612. http://dx.doi.org/10.1108/14626000510628252 
